\title{
PENERAPAN KONSEP MATEMATIKA DALAM PEMBELAJARAN BAHASA ARAB PADA FTK DI UIN STS JAMBI
}

\author{
Yogia Prihartini ${ }^{1}$, Wahyudi ${ }^{2}$, Nuraini ${ }^{3}$ dan Muhammad Ridha DS ${ }^{4}$ \\ ${ }^{1,2}$ Universitas Islam Negeri Sulthan Thaha Saifuddin Jambi \\ ${ }^{3}$ Madrasah Tsanawiyah Negeri 4 Aceh Utara \\ ${ }^{4}$ Institut Agama Islam Negeri Kerinci \\ e-mail: yogia_prihartini@yahoo.com
}

\begin{abstract}
Learning of Arabic language develops oral and written communication skills to understand and disclose information, thoughts, feelings, and the development of science and technology and culture. Besides applying appropriate methods and techniques in learning Arabic, media selection is also very necessary in improving the quality of the learning processe. This is a qualitative research. The subjects of this research are a lecturer of Arabic and students of Mathematics study program. The data are collecting through observations, interviews and documentation. The data has been analyzed and then presented inductively, deductively and comparatively. This research focused on how to describe the strategy of learning Mathematics in Arabic, how the concept of learning Arabic that needs to be applied in learning Mathematics. The results show that the concept of Mathematics learning is not only applied in Mathematics learning itself, but can be applied in Arabic learning such as counting operations in addition, subtraction, multiplication, and division. The main concept to be considered for an educator, he must prepare first, then just master the lessons that will be taught to his students through the concept of giving a lot of exercises, mastering Arabic and while teaching in the classroom must speak in Arabic. Please note that every student is required to study Arabic and associate Arabic learning with other learning, especially mathematics lessons and thus students will be able to develop and apply it in everyday life.
\end{abstract}

Keyword: Mathematical Concepts, Arabic Language Learning

\begin{abstract}
Abstrak. Pembelajaran Bahasa Arab merupakan mata pelajaran yang mengembangkan keterampilan berkomunikasi lisan dan tulisan untuk memahami dan mengungkapkan informasi, pikiran, perasaan serta pengembangan ilmu dan teknologi dan budaya. Selain metode dan teknik dalam pembelajaran bahasa Arab, pemilihan media juga sangat perlu dalam meningkatkan kualitas proses dan hasil pembelajaran bahasa Arab itu sendiri. Jenis penelitian ini adalah penelitian kualitatif. Adapun subjek dalam penelitian ini adalah dosen bahasa Arab dan mahasiswa Jurusan Prodi Pendidikan Matematika untuk memperoleh data penulis melakukan observasi, wawancara dan dokumentasi. Data yang telah diperoleh kemudian dianalisa kemudian disajikan secara induktif, deduktif dan komparatif. Penelitian ini difokuskan untuk mendeskripsikan tentang bagaimana strategi pembelajaran Matematika dalam bahasa Arab, bagaimana konsep pembelajaran Bahasa Arab yang perlu diterapkan dalam pembelajaran Matematika. Hasil penelitian menunjukkan bahwa konsep pembelajaran Matematika tidak hanya diterapkan dalam pembelajaran Matematika sendiri, akan tetapi dapat diterapkan dalam pembelajaran bahasa Arab seperti operasi hitung dalam penjumlahan, pengurangan, perkalian, dan pembagian. Konsep utama yang perlu diperhatikan bagi seorang pendidik, ia harus mempersiapkan diri terlebih dahulu, kemudian baru menguasai pembelajaran yang akan diajarkan kepada anak didiknya melalui konsep memberikan banyak tamrinat, menguasai bahasa Arab dan saat mengajar di dalam ruang harus berbicara dalam bahasa Arab. Perlu diketahui bahwa setiap mahasiswa diperlukan untuk belajar bahasa Arab dan mengaitkan pembelajaran bahasa Arab dengan pembelajaran lainnya, khususnya pelajaran matematika dan dengan demikian mahasiswa akan mampu mengembangkan dan menerapkannya dalam kehidupan sehari-hari.
\end{abstract}

Kata Kunci: Konsep Matematika, Pembelajaran Bahasa Arab. 


\section{PENDAHULUAN}

Pengajaran bahasa Arab sangat menarik untuk dikaji ulang. Bukan saja karena fungsi dan esensinya bagi kehidupan komunikasi Islam, tapi karena sifatnya yang berada di tengah-tengah tradisi kependidikan yang sedang berlangsung dewasa ini memerlukan berbagai inovasi, sebagai konsekuensi logis berkembangnya sains dan teknologi. Perkembangan ilmu pengetahuan dan teknologi yang begitu pesat bagi kehidupan manusia, maka diperlukan adanya upaya pada teknisi pengajaran, yaitu pengajaran ilmu-ilmu lainnya.

Dalam proses pengajaran ada proses pembelajaran yang substansinya adalah kegiatan mengajar yang dilakukan secara maksimal oleh seorang pengajar agar anak didik yang diajari materi tertentu melakukan kegiatan belajar dengan baik. Dengan kata lain pembelajaran adalah upaya yang dilakukan oleh guru dalam menciptakan kegiatan belajar materi tertentu yang kondusif untuk mencapai tujuan. Dengan demikian, pembelajaran bahasa asing adalah kegiatan mengajar yang dilakukan secara maksimal oleh seorang pengajar agar anak didik yang diajari bahasa asing tertentu melakukan kegiatan belajar dengan baik, sehingga kondusif untuk mencapai tujuan belajar bahasa asing.

Dalam pembelajaran bahasa ada tiga istilah yang perlu dipahami pengertian dan konsepnya secara tepat, yakni pendekatan, metode dan teknik. Edward M Anthony dalam artikelnya "Approach, Method and Technique". Adapun ketiga istilah tersebut adalah sebagai berikut: (1) Pendekatan, yang dalam bahasa Arab disebut madkhal adalah seperangkat asumsi berkenaan dengan hakikat bahasa dan hakikat belajar mengajar bahasa. Pendekatan bersifat aksiomatis atau filosofis yang berorientasi pada pendirian, filsafat, dan keyakinan yaitu sesuatu yang diyakini tetapi tidak mesti dapat dibuktikan. (2) Metode, yang dalam bahasa Arab disebut thariqab adalah rencana menyeluruh yang berkenaan dengan penyajian materi bahasa secara teratur atau sistematis berdasarkan pendekatan yang ditentukan. Jika pendekatan bersifat aksiomatis, maka metode bersifat prosedural. Sehingga dalam satu pendekatan bisa saja terdapat beberapa metode. (3) Teknik, yang dalam bahasa Arab disebut uslub atau yang populer dalam bahasa kita dengan strategi, yaitu kegiatan spesifik yang diimplementasikan di dalam kelas, selaras dengan pendekatan dan metode yang telah dipilih. Teknik bersifat operasional, karena itu sangatlah tergantung pada imajinasi dan kreativitas seorang pengajar dalam meramu materi dan mengatasi dan memecahkan berbagai persoalan di kelas.

Dari paparan di atas dapat dipahami, bahwa ketiga istilah tersebut memiliki hubungan yang hierarki. Dari satu pendekatan bisa menghadirkan satu atau beberapa metode, dan dari satu metode bisa mengimplementasikan satu atau beberapa strategi. Sebaliknya strategi harus konsisten dengan metode dan karena itu tidak boleh bertentangan dengan pendekatan. 
Adapun menurut Hamalik pengertian pembelajaran adalah suatu komunikasi yang tersusun meliputi unsur manusiawi, material, fasilitas, perlengkapan dan prosedur yang saling mempengaruhi untuk mencapai tujuan pembelajaran, dalam hal ini manusia terlibat dalam sistem pengajaran terdiri dari peserta didik, pengajar/ pendidik dan tenaga lainnya. Dalam pembelajaran terjadi interaksi antara pendidik dan peserta didik, di satu sisi pengajar melakukan sebuah aktivitas yang membawa anak ke arah tujuan, lebih dari itu anak didik dapat melakukan serangkaian kegiatan yang telah direncanakan oleh pengajar yaitu kegiatan belajar yang terarah pada tujuan yang ingin dicapai.

Sementara itu, bahasa Arab merupakan salah satu bahasa dunia yang telah mengalami perkembangan sosial masyarakat dan ilmu pengetahuan. Bahasa Arab dalam kajian sejarah termasuk rumpun bahasa Semit yaitu rumpun rumpun bahasa yang dipakai bangsa-bangsa yang tinggal di sekitar sungai Tigris dan Furat, dataran Syria dan Jazirah Arabia (Timur Tengah). Dengan demikian pembelajaran bahasa Arab dapat didefinisikan suatu upaya membelajarkan siswa untuk belajar bahasa Arab dengan guru sebagai fasilitator dengan mengorganisasikan berbagai unsur untuk memperoleh tujuan yang ingin dicapai.

Pembelajaran bahasa diperlukan agar seseorang dapat berkomunikasi dengan baik dan benar dengan sesamanya dan lingkungannya, baik secara lisan maupun tulisan. Tujuan pembelajaran bahasa adalah untuk menguasai ilmu bahasa dan kemahiran berbahasa Arab, seperti muthala'ah, muhadatsah, insya', nabwu dan sharaf, sehingga memperoleh kemahiran berbahasa yang meliputi empat aspek kemahiran, yaitu: (1) Kemahiran menyimak :Kemahiran menyimak sebagai kemahiran berbahasa yang sifatnya reseptif, menerima informasi dari orang lain (pembicara). (2) Kemahiran membaca : Kemahiran membaca merupakan kemahiran berbahasa yang sifatnya reseptif, menerima informasi dari orang lain (penulis) di dalam bentuk tulisan. Membaca merupakan perubahan wujud tulisan menjadi wujud makna. (3) Kemahiran menulis : Kemahiran menulis merupakan kemahiran bahasa yang sifatnya yang menghasilkan atau memberikan informasi kepada orang lain (pembaca) di dalam bentuk tulisan. Menulis merupakan perubahan wujud pikiran atau perasaan menjadi wujud tulisan. (4) Kemahiran berbicara : Sedangkan kemahiran berbicara merupakan kemahiran yang sifatnya produktif, menghasilkan atau menyampaikan informasi kepada orang lain (penyimak) di dalam bentuk bunyi bahasa (tuturan merupakan proses perubahan wujud bunyi bahasa menjadi wujud tuturan

Departemen Agama menjelaskan bahwa tujuan umum pembelajaran bahasa Arab adalah: (1) Untuk dapat memahami Al-Quran dan hadist sebagai sumber hukum ajaran Islam. (2) Untuk dapat memahami buku-buku agama dan kebudayaan Islam yang ditulis dalam bahasa Arab. (3) Untuk dapat berbicara dan mengarang dalam bahasa Arab. (4) Untuk dapat digunakan sebagai 
alat pembantu keahlian lain (supplementary). (5) Untuk membina ahli bahasa Arab, yakni benarbenar profesional. Di samping itu tujuan pengajaran bahasa Arab adalah untuk memperkenalkan berbagai bentuk ilmu bahasa kepada peserta didik yang dapat membantu memperoleh kemahiran berbahasa, dengan menggunakan berbagai bentuk dan ragam bahasa untuk berkomunikasi, baik dalam bentuk lisan maupun tulisan, untuk tercapainya tujuan tersebut para pengajar atau ahli bahasa, pembuat kurikulum atau program pembelajaran harus memikirkan materi atau bahan yang sesuai dengan tingkat kemampuan peserta didik serta mencari metode atau teknik pengajaran ilmu bahasa dan kemahiran berbahasa Arab, dan melatih peserta didik dalam kehidupan sehari-hari, baik kemahiran membaca, menulis dan berbicara.

Kemahiran dasar yang harus dimiliki dalam memahami bahasa Arab dalam menguasai ilmu bahasa dan kemahiran berbahasa Arab beserta kaidahnya-kaidahnya, menghafal atau menguasai kosa kata (mufradat) beserta artinya. Kaidah-kaidah bahasa Arab dipelajari dalam mata kuliah nabwu dan sharaf. Sedangkan mufradat dapat dikuasai melalui mata kuliah muthala'ah dan mubadatsah, karena kedua mata kuliah tersebut sangat bergantung pada penguasaan kosa kata. Dalam menguasai kaidah-kaidah bahasa Arab memerlukan kepada penguasaan nahwu dan sharaf. Nahwu digunakan untuk mempelajari struktur kalimat dan perubahan baris akhir. Sedangkan sharaf digunakan untuk mempelajari dasar kata beserta perubahannya. Selanjutnya untuk memperoleh kemahiran menyimak dan membaca perlu mempelajari ilmu muthala'ah. Untuk memperoleh kemahiran menulis atau mengarang perlu mempelajari ilmu insya' dan untuk memperoleh kemahiran berbicara perlu mempelajari ilmu muhadatsah.

Sedangkan pentingnya pembelajaran bahasa Arab yaitu bahasa Arab merupakan salah satu bahasa besar yang banyak digunakan di berbagai pelosok dunia. Sejak abad pertengahan bahasa Arab menjadi bahasa universal yang akhirnya menjadikannya salah satu dari beberapa bahasa terbesar di dunia seperti bahasa Yunani, bahasa Latin, bahasa Inggris, bahasa Perancis, bahasa Spanyol, dan bahasa Rusia. Dan saat ini bahasa Arab merupakan salah satu bahasa yang dipergunakan untuk menulis dokumen-dokumen Perserikatan Bangsa Bangsa (PBB). Disisi lain, bahasa Arab adalah juga bahasa Al-Qur'an, hal inilah yang menjadikan bahasa Arab menjadi bahasa yang sangat berkaitan dengan Islam, sebab ia adalah bahasa Agama untuk semua umat Islam di dunia, baik bagi mereka yang mempergunakan bahasa Arab dalam kehidupan sehari-hari mereka maupun tidak. Hal ini disebabkan karena orang-orang Islam membaca Al-Qur'an dalam bahasa aslinya, yaitu bahasa Arab. Tidak ada terjemahan Al-Qur'an yang dibuat dalam semua bahasa yang memungkinkan mereka untuk menggantikan bahasa aslinya. Begitu pula sholat lima waktu dan doa-doa, serta azan semuanya mempergunakan bahasa Arab fusha. 
Dari fakta dan realita di atas, kita dapat mengetahui dan memahami akan pentingnya bahasa Arab, khususnya bagi umat Islam baik yang berdomisili di Arab maupun di negara lainnya. Akan tetapi yang menjadi permasalahan adalah dalam pembelajarannya bagi orang-orang asing (non-Arab), seperti halnya pembelajaran bahasa Arab di negara kita Indonesia yang mana mayoritas penduduknya adalah umat Islam. Telah kita ketahui juga, bahwa bahasa Arab adalah salah satu bahasa Asing yang diajarkan di sebagian sekolah-sekolah di Indonesia, baik itu sekolahan di kota maupun di desa-desa. Dan kebanyakan, bahasa Arab diajarkan di madrasahmadrasah dan pondok-pondok pesantren yang tersebar di seluruh wilayah Indonesia, mulai dari sekolah dasar sampai perguruan tinggi.

Pada dasarnya, pembelajaran bahasa asing tidaklah mudah, akan tetapi seringkali terdapat kesulitan-kesulitan yang dihadapi oleh guru dan murid. Sebagian dari kesulitan-kesulitan itu adalah seperti yang dikatakan oleh Muhammad Athiyah Al-Abrasyi, bahwa dalam pembelajaran bahasa asing, sebagian besar murid masih menghafalkan kalimat-kalimat (vocabularies) akan tetapi tidak mampu memahami maknanya. Seharusnya guru tidak boleh memaksa dan membebani murid dengan hafalan kalimat yang tidak diketahui maknanya, karena hal tersebut bukanlah cara yang baik untuk mempelajari bahasa asing. Berdasarkan hal tersebut, tentunya kita membutuhkan strategi yang jitu dalam mengatasi kesulitan-kesulitan dalam pembelajaran bahasa asing, khususnya bahasa Arab. Hal ini dimaksudkan agar pembelajaran bisa mencapai target dan tujuan yang telah ditetapkan.

Secara bahasa kemampuan sama dengan kesanggupan atau kecakapan. Kemampuan merupakan kesanggupan individu untuk melakukan pekerjaan yang dibebankan. Sedangkan kemampuan berbahasa adalah kemampuan individu untuk mendengarkan ujaran yang disampaikan oleh lawan bicara, berbicara dengan lawan bicara, membaca pesan-pesan dalam bentuk tulis, dan menulis pesan-pesan baik secara lisan maupun tulisan. Jadi kemampuan berbahasa Arab adalah kemampuan individu untuk mendengarkan ujaran yang disampaikan oleh lawan bicara, berbicara dengan lawan bicara, membaca pesan-pesan dalam bentuk tulis, dan menulis pesan-pesan baik secara lisan maupun tulisan dalam bahasa Arab. Berikut ini, jenis-jenis kemampuan berbahasa, yaitu: (1) Kemampuan Menyimak (mendengar), kemampuan menyimak atau mendengar adalah kemampuan menangkap dan memproduksi bahasa yang diperoleh dengan pendengaran yang bertujuan agar siswa dapat memahami ajaran dalam bahasa Arab, baik bahasa sehari-hari maupun bahasa yang digunakan dalam forum resmi. (2) Kemampuan Berbicara, kemampuan berbicara adalah kemampuan berkomunikasi secara langsung dalam bentuk percakapan atau dialog tujuannya agar siswa terampil berbicara atau menggunakan lisan. (3) Kemampuan Membaca, kemampuan membaca adalah kemampuan melihat atau memahami isi 
dari apa yang tertulis dengan melisankan atau di dalam hati dan mengeja atau melafalkan yang tertulis. (4) Kemampuan menulis, kemahiran menulis merupakan suatu keterampilan berbahasa yang dipergunakan untuk berkomunikasi secara tidak langsung atau tidak secara tatap muka dengan orang lain. Kemampuan menulis adalah terampil membuat huruf-huruf besar maupun kecil dengan jalan menyalin atau meniru tulisan-tulisan dalam struktur kalimat namun yang lebih penting adalah kemampuan merangkai bahasa atau mengarang.

Perlu diperhatikan dalam pembelajaran bahasa Arab dengan tujuan untuk menghilangkan kesan bahwa bahasa Arab itu sulit dan memusingkan maka guru harus mengerti tingkatan murid yang sedang diajar, agar bisa memberikan materi sesuai dengan tingkat siswa pada saat itu. Pemberian materi yang sesuai akan mempercepat pemahaman siswa, jangan sampai pada saat siswa masih pada tahap pemula (mubtadi'in) dalam mempelajari bahasa Arab, guru memberikan materi yang terlalu sulit seperti mengarang, bercerita dalam bahasa Arab tentu itu akan membuat siswa yang baru belajar bahasa Arab akan merasa sangat kesulitan, sehingga timbullah kepahaman pada diri siswa bahwa bahasa Arab itu sulit, begitu juga sebaliknya pemberian materi yang terlalu ringan kepada siswa yang sudah pada tingkat mahir (mutaqaddimin) akan membuat siswa merasa cepat bosan karena meteri itu sudah dia kuasai, pengenalan awal terhadap tingkatan siswa akan sangat membantu seorang guru dalam memberikan sebuah materi yang cocok, hal ini sesuai dengan yang dikatakan Yusuf bahwa pembelajaran bahasa Arab perlu dipersiapkan materi dengan baik yang disesuaikan dengan taraf perkembangan anak didik.

Untuk menghindari kesan bahwa belajar bahasa Arab itu sulit maka yang harus kita laksanakan adalah: (1) Mengajarkan bahasa Arab percakapan dengan kata-kata yang sederhana dan mudah dimengerti oleh peserta didik. (2) Menggunakan media, hal ini penting agar pembelajaran menarik, bergairah, dan mudah dipahami. (3) Mengaktifkan seluruh panca indra anak didik, lidah dilatih dengan percakapan, mata dilatih dengan membaca, dan tangan dilatih dengan menulis dan mengarang. Dalam Pembelajaran bahasa Arab telah kita ketahui bahwa tingkatan pembelajaran bahasa Arab terdiri atas: (1) Mubtadi'in (pemula) ini adalah tingkatan yang paling awal dalam pembelajaran bahasa Arab, dan biasanya materi yang paling cocok untuk tingkatan ini adalah: menghafalkan mufrodat, percakapan yang sederhana, dan mengarang terarah (insya' muwajahah) ini biasanya digunakan pada level bawah karena ia mencakup kegiatan mengarang yang dimulai dari merangkai huruf, kemudian kata dan kalimat. (2) Mutawasitin (menengah) ketika siswa pada tingkatan ini berarti dia sudah mendapatkan beberapa materi tentang bahasa Arab, dan tugas seorang guru pada saat itu adalah memberi penguatan terhadap materi-materi yang sudah didapatkan oleh siswa, sehingga bisa mahir dalam materi tersebut. (3) Mutaqodimin (mahir) pada tingkatan ini siswa sudah mulai mahir terhadap materi-materi berbahasa 
Arab dan materi yang sesuai bagi siswa yang sudah pada tingkatan ini adalah mengarang bebas (insya bur) ini biasanya digunakan pada level tingkat tinggi karena disitu keterampilan, kreativitas dari seorang penulis sangat diandalkan.

Adapun terdapat pendapat lain dalam tingkatan-tingkatan dalam pembelajaran bahasa Arab, yaitu tingkat pemula diterjemahkan dengan al-Marhalat al-Ûla, dalam bahasa Inggris disebut dengan Elementary Level. Sementara tingkat menengah dalam bahasa Arab diterjemahkan dengan al-Marhalat al-Mutawassithah, dalam bahasa Inggris disebut dengan Intermediate Level. Menurut AlHadîdi, istilah tingkat pemula atau menengah dalam dunia pembelajaran bahasa, termasuk bahasa Arab, dapat diukur dari dua aspek: pertama, aspek jumlah penguasaan mufradât siswa. Untuk tingkat pemula, mufradât yang harus dikuasainya adalah $0 \mathrm{~s} / \mathrm{d}$. 1.000 kata, demikian juga untuk tingkat menengah, $(1.000 \mathrm{~s} / \mathrm{d}$. $2.000 \mathrm{kata})$. Kedua, dari segi jumlah jam pelajaran. Untuk tingkat pemula, jumlah jam pelajaran yang harus dilalui mencapai 0 s/d. 250 jam; 200 jam dihabiskan secara formal di sekolah dan 50 jam untuk tugas dll. Jumlah dan alokasi jam di atas, juga berlaku untuk "tingkat menengah" yaitu 250 jam pelajaran: yang terdiri dari: 200 jam di kelas (dalam bimbingan guru), dan selebihnya di luar kelas, seperti tugas harian (minimal dua jam dalam sehari) baik secara mandiri maupun berkelompok. Memperhatikan batasan di atas, dapat diketahui bahwa dikatakan tingkat pemula jika telah menguasai mufradat sejumlah 1.000 kata. Sementara untuk beranjak pada tingkat menengah harus menguasai 2.000 mufaradat. Di sisi lain, jumlah jam pelajaran yang harus dilewati mencapai 250 jam.

Berdasarkan batasan di atas, istilah pemula atau menengah tidak harus dipahami secara formal, seperti menyamakan pemula dengan SD atau MI, serta SLTP atau MTs dan SLTA atau Madrasah Aliyah dengan menengah, karena masing-masing level tersebut diukur dengan penguasaan sejumlah kosa kata dan sejumlah jam pelajaran yang telah dilalui. Maka boleh saja seseorang yang telah berumur 30 tahun namun baru mulai belajar bahasa disebut sebagai pemula, atau sebaliknya siswa yang baru berumur 10 tahun, tapi telah menguasai kosa kata dan jam pelajaran setingkat menengah disebut sebagai level menengah. Hal ini juga berlaku pada penerapan konsep matematika dalam pembelajaran bahasa Arab.

Bagaimana matematika seharusnya dipelajari?. Pertanyaan ini nampaknya sederhana, akan tetapi memerlukan jawaban yang tidak sederhana. Karena pandangan pengajar tentang proses belajar matematika sangat berpengaruh terhadap bagaimana mereka melakukan pembelajaran di kelas, maka teori-teori yang berkaitan dengan belajar matematika harus menjadi prioritas bagi para pendidik matematika. Uraian di atas mengharapkan dalam proses pembelajaran matematika di kelas, hendaknya peserta didik diberi kesempatan untuk menemukan fakta dan menyusun konsep-konsep matematika di bawah bimbingan pendidik. Setelah peserta didik menemukan dan 
mengerti konsep-konsep, siswa diberikan masalah-masalah real untuk mengaplikasikan konsep yang telah mereka pelajari. Dengan demikian peserta didik dapat merasakan manfaat matematika dalam menyelesaikan permasalahan.

Bahwasanya pembelajaran matematika yang berlangsung selama ini di Indonesia masih didominasi oleh pandangan behavioristik. Guru memberi penjelasan tentang konsep-konsep matematika, memberikan contoh-contoh, latihan dan pekerjaan rumah. Sedangkan peserta didik belum diberikan kesempatan untuk menemukan kembali konsep-konsep tersebut. Kalau dilihat bagaimana bentuk kegiatan mengajar, maka kegiatan yang dilakukan pengajar/pendidik selama ini belumlah termasuk mengajar yang sesungguhnya. Berdasarkan Standar Kompetensi dan Kompetensi Dasar mata pelajaran Matematika Peraturan Menteri Pendidikan Nasional Nomor 22 Tahun 2006. Tujuan umum diberikannya matematika di jenjang pendidikan dasar, menengah, tinggi adalah sebagai berikut: (1) Memahami konsep matematika, menjelaskan keterkaitan antar konsep dan mengaplikasikan konsep atau algoritma, secara luwes, akurat, efisien, dan tepat, dalam pemecahan masalah. (2) Menggunakan penalaran pada pola dan sifat, melakukan manipulasi matematika dalam membuat generalisasi, menyusun bukti, atau menjelaskan gagasan dan pernyataan matematika. (3) Memecahkan masalah yang meliputi kemampuan memahami masalah, merancang model matematika, menyelesaikan model dan menafsirkan solusi yang diperoleh. (4)

Mengkomunikasikan gagasan dengan simbol, tabel, diagram, atau media lain untuk memperjelas keadaan atau masalah. (5) Memiliki sikap menghargai kegunaan matematika dalam kehidupan, yaitu memiliki rasa ingin tahu, perhatian, dan minat dalam mempelajari matematika, serta sikap ulet dan percaya diri dalam pemecahan masalah.

Secara umum tujuan pendidikan matematika pada di jenjang pendidikan dasar, menengah, tinggi lebih menekankan pada penataan nalar, pembentukan sikap, penguasaan bahan ajar serta keterampilan menerapkan matematika dalam penyelesaian masalah baik di ilmu lain maupun yang ditemui di kehidupan sehari-hari.

Dari paparan teori di atas, ada hal yang menarik untuk dibahas berdasarkan pada sorotan yang bernada kritik dari para ahli dan masyarakat terhadap kemampuan pelajar atau siswa, khususnya siswa IAIN atau STAIN terhadap bahasa Arab. Dari fenomena yang ada, diantara lembaga pendidikan Islam yang ada di Indonesia, lebih banyak meninggalkan kesan akan pentingnya pengajaran penguasaan bahasa Arab yang diterapkan dalam pembelajaran matematika dan ilmu sains. Sehingga hal inilah yang melatarbelakangi penulisan ini,sehingga apa yang kita temui di lapangan bahwa meskipun seorang pengajar yang sangat menguasai segi tata bahasa Arab, tetapi lemah dalam hal memfungsikan bahasa Arab itu sendiri, sebagai konsep bahasa dalam pengajaran ilmu lainnya juga akan dapat ditemui konsep yang baik untuk pembelajaran. 
Oleh karena itu, peneliti akan membahas dan mengangkat tema tentang "Penerapan Konsep Bahasa Arab dalam Pembelajaran Matematika”. Karena itu, peneliti menyusun rumusan masalah sebagai berikut: 1)Bagaimanakah strategi pembelajaran Matematika dalam bahasa Arab?, 2).Bagaimanakah konsep pembelajaran Bahasa Arab yang perlu diterapkan dalam pembelajaran Matematika?. Adapun tujuan dari penulisan ini adalah sebagai berikut: 1).Untuk mengetahui strategi pembelajaran Matematika dalam bahasa Arab, 2).Untuk mengetahui konsep penerapan Bahasa Arab yang diterapkan dalam pembelajaran Matematika

\section{METODOLOGI}

Jenis penelitian yang penulis gunakan dalam penelitian ini adalah penelitian lapangan (field research), dimana penulis terjun langsung ke dalam lingkungan yang diteliti, yaitu Fakultas Tarbiyah dan Keguruan di UIN Sulthan Thaha Saifuddin Jambi. Jenis data yang akan di kumpulkan terdiri atas data primer dan data sekunder. Data primer adalah data yang bersumber langsung dari hasil wawancara dengan Ketua Jurusan, Dosen Bahasa Arab dan Mahasiswa Tadris Pendidikan Matematika. Adapun data sekunder adalah data penunjang yang berasal dari sumber-sumber dan dokumentasi-dokumentasi yang diperoleh dari Fakultas Tarbiyah Dan Keguruan, dan data sekunder ini juga berasal dari beberapa buku yang menjadi sumber data untuk mendapatkan teoriteori dari para ahli sebagai referensi.

Sumber data yang berbentuk teori, bersumber dari buku-buku yang referensi yang berhubungan dengan masalah yang di bahas dalam penelitian ini. Sedangkan sumber data lapangan diperoleh dari Ketua Jurusan, dosen bahasa Arab dan mahasiswa. Jika diperlukan beberapa sumber lainnya juga akan menjadi sumber data, selagi sumber tersebut masih menyangkut dengan keperluan dan kebutuhan yang berhubungan dengan penelitian yang penulis lakukan ini sejauh tidak menghambat proses penelitian maka peristiwa juga dijadikan sumber data. Adapun populasi dalam penelitian ini adalah seluruh mahasiswa jurusan Pendidikan Matematika pada Fakultas Tarbiyah dan Keguruan di UIN Sulthan Thaha Saifuddin Jambi dan Sampel dalam penelitian yang digunakan dalam penelitian ini adalah Mahasiswa Jurusan Prodi Pendidikan Matematika yang terdiri dari 4 kelas yaitu Kelas A, Kelas B, Kelas C, dan Kelas D yang mana diambil 10 mahasiswa pada masing-masing kelas tersebut.

Untuk mengumpulkan data yang diperlukan dalam penelitian ini, penulis menggunakan beberapa metode pengumpulan data yaitu (1) observasi adalah memperhatikan sesuatu dengan menggunakan mata. Metode observasi penulis gunakan untuk mengamati secara langsung tentang keadaan umum Fakultas Tarbiyah Dan Keguruan yang meliputi letak geografis, dan proses pembelajaran bahasa Arab. (2) wawancara adalah sebuah dialog yang dilakukan pewawancara 
untuk memperoleh informasi dari terwawancara. Metode wawancara dimaksud untuk mendapatkan data yang perlu adanya penjelasan dari informan, dalam pelaksanaannya peneliti langsung bertatap muka dengan informan dalam hal ini guru bahasa Arab untuk mengetahui kemampuan mahasiswa Fakultas Tarbiyah dan Keguruan dalam menguasai bahasa Arab. dokumentasi adalah metode untuk mencari data mengenai hal-hal atau variabel yang berupa catatan, transkip, buku, surat kabar, majalah prasasti, notulen rapat, lengger, agenda dan lain-lain. Dalam penelitian ini metode dokumentasi penulis gunakan untuk mendapatkan catatan atau arsip yang berhubungan dengan penelitian. Letak geografis, struktur organisasi sekolah, sarana dan prasarana sekolah serta keadaan dosen karyawan dan mahasiswa serta nilai belajar bahasa Arab mahasiswa.

Metode analisa data yang dipergunakan dalam penelitian ini adalah model analisa data mengalir, berarti bahwa penulis harus melakukan analisa sepanjang penelitian dilakukan, selama penulis masih melakukan penelitian, selama itulah penulis tetap melakukan analisa data. Pada tahap pertama, data yang diperoleh dari hasil observasi, wawancara, dan dokumentasi serta literatur di edit dengan tujuan untuk meneliti ketepatan, kelengkapan dan kebenaran data. Kemudian, data tersebut disusun berdasarkan kategorisasi yang sesuai dengan masalah dan kebutuhan penelitian. Selanjutnya dibuat kesimpulan sementara, pada tahap berikutnya dilakukan analisa data dengan tujuan untuk memperoleh berbagai kesimpulan. Pada tahap kesimpulan maka analisa data disesuaikan dengan jenis data yang diperoleh dan jenis masalah yang akan dikaji. Kesimpulan-kesimpulan yang ada itu perlu diverifikasikan lebih lanjut, dari analisa data terakhir inilah dapat ditarik kesimpulan atas hasil penelitian yang dilakukan di lapangan.

\section{HASIL PENELITIAN DAN PEMBAHASAN}

\section{Strategi Pembelajaran Bahasa Arab dalam Konsep Matematika}

Operasi Penjumlahan di dalam bahasa Arab disebut dengan عملية الجمع. contohnya, Jika kita mendapatkan kalimat matematika seperti berikut ini:

$$
\begin{array}{r}
7=4+3 \\
20=8+6+5+1
\end{array}
$$

Dalam bahasa Arab, cara membacanya yaitu dengan memulainya dari sebelah kanan yang terlihat seperti yang di bawah ini:

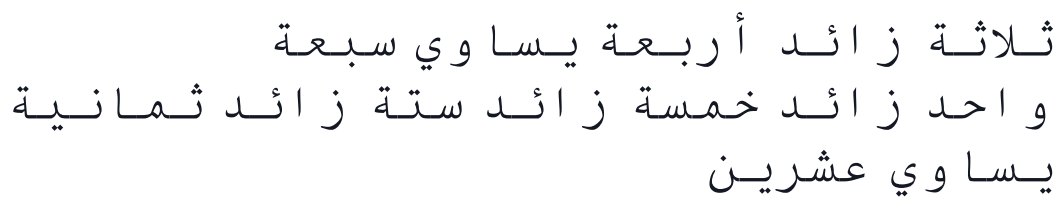


Demikianlah cara membaca operasi penjumlahan dalam bahasa Arab. Sekarang kita akan mencoba membaca operasi pengurangan. Operasi pengurangan dalam bahasa Arab disebut dengan عملية الطرح. Misalnya, Jika Anda mendapatkan kalimat matematika seperti berikut ini:

Maka dibaca:

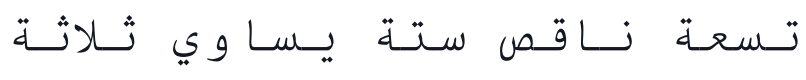

(Tis'ah naaqish sittah yusaawii tsalaatsah)

Oleh karena itu Implikasi Konsep Pembelajaran Bahasa Arab dalam Pembelajaran Matematika di antaranya adalah: (1) Usaha keras seorang pengajar dalam mengajar tidak mesti diikuti dengan hasil yang bagus pada mahasiswanya. Setiap mahasiswa harus mengkonstruksi (membangun) pengetahuan matematika di dalam benaknya masing-masing berdasar pada kerangka kognitif yang sudah ada di dalam benaknya. (2) Tugas setiap pengajar adalah memfasilitasi mahasiswanya, sehingga pengetahuan matematika dibangun atau dikonstruksi para mahasiswa sendiri dan bukan ditanamkan oleh para pengajarnya. (3) Untuk mengajar dengan baik, pengajar harus memahami model-model mental yang digunakan para mahasiswa, karenanya para pengajar harus mau bertanya dan mau mengamati pekerjaan mahasiswanya. Setiap kesalahan mahasiswa harus menjadi umpan balik dalam proses penyempurnaan rancangan proses pembelajaran berikutnya. (4) Mahasiswa perlu mengkonstruksi pemahaman mereka sendiri untuk masing-masing konsep matematika sehingga peranan pengajar membantu perkembangan mahasiswa membuat konstruksi-kontruksi mental yang diperlukan.

\section{Penerapan Konsep Pembelajaran Bahasa Arab dalam Pembelajaran Matematika}

Gagasan-gagasan tentang konsep pengajaran bahasa Arab tampak belum sampai pada titik produksi dan ekspor, tetapi tampaknya masih harus dipetikemaskan dari Amerika atau Eropa lantas diberi label Arab, sehingga suatu institusi perguruan tinggi di Afrika yang menghasilkan beberapa master pengajaran bahasa Arab di Indonesia ini nampaknya belum mampu berbicara di atas landasan metodologi yang provokatif-implementatif serta research yang mapan. Konsep seperti yang diungkapkan oleh Abd. Kadir Ahmad bahwa konsep ini pantas diberi nama dengan metode tradisional. Metode semacam ini biasanya berlandaskan pada apa yang disebut dengan نظرية الفروع atau teori cabang-cabang dan bukan pada نظرية الوحدة atau teori kesatuan.

Kalau diamati secara cermat, konsep ini cukup banyak membawa keberhasilan. Kekurangannya adalah tidak munculnya semacam riset estafet dikalangan pengajar bahasa Arab tentang konsep ini, dan tampak kurang dipraktekkan di madrasah ibtidaiyah, Tsanawiyah, dan Aliyah 
yang dikelola oleh Departemen Agama. Kendala utama biasanya lahir dari pengajar bahasa Arab itu sendiri.

Konsep umum pembelajaran bahasa Arab yang biasanya diterapkan dalam pembelajaran Matematika adalah sebagai berikut:

1. Persiapan

Seorang guru yang baik harus selalu mempersiapkan pembelajaran bahasa Arab dalam dalam setiap topik bahasan pembelajaran matematika. Tujuan pembelajaran bahasa Arab yang akan diajarkan dalam pembelajaran matematika harus jelas ,cara-cara dan teknik serta taktik yang akan diberikan hendaklah senantiasa dipikirkan .

2. Menghitung matematika dalam bahasa Arab

Menghitung matematika dalam bahasa Arab membutuhkan keterbiasaan sesegera mungkin akan bunyi yang belum familiar bagi mereka. Dalam bahasa Arab, cara membacanya yaitu dengan memulainya dari sebelah kanan sebagaimana yang telah diurai sebelumnya di atas.

3. Jangan pindah sebelum mantap,jangan tertipu oleh jawaban bersama

Menguasai suatu pembelajaran bahasa Arab dalam pembelajaran matematika bagaikan membangun sebuah batu. Pembangunan harus dimulai dengan memasang pondasi, kemudian batu batanya disemen supaya tidak goyah. Dalam kondisi yang demikian itu,bila ada pemasangan batu yang kurang kuat,maka kontruksi keseluruhan akan lemah.

Perkenalkanlah struktur-struktur baru pembelajaran bahasa Arab dalam pembelajaran matematika secara lisan,dengan memakai alat peraga yang efektif. Tulis di papan tulis dan suruh mereka menyalin. Mereka harus memahami pokok bahasan pembelajaran bahasa Arab dalam pembelajaran matematika dan tahu memakainya sebelum pindah ke pokok pembahasan selanjutnya. Guru tidak boleh terkecoh oleh jawaban bersama.

4. Buku bukan guru tetapi alat pembantu

Buku berfungsi sebagai media untuk mempermudah tugas guru dalam pembelajaran bahasa Arab yang diterapkan dalam pembelajaran matematika,bukan sebagai guru,karena buku tidak dapat berbicara, mendengar, mengoreksi atau memberi dorongan. Guru-guru yang baru terjun mengajar dalam pembelajaran bahasa Arab yang diterapkan dalam pembelajaran matematika,akan gampang terperangkap ke dalam apa yang disebut "the textbook trap". Oleh karena itu,sebaiknya buku teks hanya dijadikan pelengkap. Adapun pengenalan terhadap materi yang baru dan lisan hendaklah datang dari guru. 


\section{PENUTUP}

Berdasarkan dari keseluruhan hasil penelitian dan analisa data yang telah dipaparkan di atas, maka dapat penulis simpulkan sebagai berikut: (1) Pembelajaran bahasa Arab dapat didefinisikan suatu upaya membelajarkan siswa untuk belajar bahasa Arab dengan guru sebagai fasilitator dengan mengorganisasikan berbagai unsur untuk memperoleh tujuan yang ingin dicapai. (2) Tujuan pembelajaran bahasa adalah untuk menguasasi ilmu bahasa dan kemahiran berbahasa Arab, seperti muthala'ah, mubadatsah, insya', nahwu dan sharaf, sehingga memperoleh kemahiran berbahasa yang meliputi empat aspek kemahiran. Sedangkan pentingnya pembelajaran bahasa Arab adalah bahasa Arab merupakan bahasa Al-Qur'an, hal inilah yang menjadikan bahasa Arab menjadi bahasa yang sangat berkaitan dengan Islam, sebab ia adalah bahasa Agama untuk semua umat Islam di dunia, baik bagi mereka yang mempergunakan bahasa Arab dalam kehidupan sehari-hari mereka maupun tidak. (3) Beberapa tingkatan dalam pembelajaran bahasa Arab adalahpertama, Mubtadi' (pemula), kedua, Mutawassith (Menengah), Ketiga, Mutaqaddim (mahir). (4) Cara baca penjumlahan dan pengurangan dalam bahasa Arab yaitu dimulai dari sebelah kanan. (5) Konsep pengajaran bahasa Arab yang perlu diterapkan dalam pembelajaran matematika bisa dimulai dengan mempersiapkan topik bahasa pembelajarannya serta tujuan yang akan diajarkan pada materi tersebut. (6) Konsep pembelajaran menghitung matematika dalam kaidah berbahasa Arab dimulai dengan membacanya dari sebelah kiri. (7) Strategi yang harus dipersiapkan oleh seorang guru dalam pengajarannya bisa dibentuk dengan aspek persiapan, ada alat pembantu seperti buku, dan lain lain.

\section{REFERENSI}

Albantani, A. M. (2015). Implementasi Kurikulum 2013 Pada Pembelajaran Bahasa Arab di Madrasah Ibtidaiyah, Arabiyat. Jurnal Pendidikan Bahasa Arab dan Kebahasaan. 2 (2).

Arikunto, S. (2006). Prosedur Penelitian Suatu Pendekatan Praktek. Jakarta: Rineka Cipta.

Arsyad, A. (2003). Bahasa Arab dan Metode Pengajarannya. Surabaya: Pustaka Pelajar.

Astuti, Y. W. (2014). Pengaruh Penggunaan Media Film Animasi Terhadap Keterampilan Menulis Karangan Narasi Siswa Kelas V SD. Jurnal Prima Edukasia. 2 (2).

Departemen Pendidikan Nasional. (2003). Standar Kompetentsi Pelajaran bahasa Arab untuk Sekolab Menengah dan Madrasah Aliyah. Jakarta: Pusat Kurikulum, Balitbang Depdiknas.

Effendi, A. F. (2005). Metodologi Pengajaran Bahasa Arab. Malang: Misykat.

Hermawan, A. (2011). Metodologi Pembelajaran Bahasa Arab. Bandung: PT Remaja Rosdakarya.

Isnaningsih, T. (2015). Pengembangan Multimedia Pembelajaran Bahasa Arab Berbantuan Komputer. Jurnal Dewantara. 1 (2).

Izzan, A. (2004). Metodologi Pembelajaran Bahasa Arab. Bandung: Humaniora.

Munawwari, A. (2007). Belajar Cepat Tata Bahasa Arab. Yogyakarta: Nurma Media Idea. 
Nurbayan, Y. (2008). Metodologi Pembelajaran Bahasa Arab. Bandung : Zein Al-Bayan.

Rahardjo, M. (2002). Relung-Relung Bahasa, Bahasa Dalam Wacana Politik Indonesia Komtemporer. Yogyakarta: Aditya Media.

Rosyidi, A. W dan Ni'mah, M. (2011). Memahami Konsep Dasar Pembelajaran Bahasa Arab. Malang: UIN-Maliki Press.

Sukamto, I. (2004). Tata Bahasa Arab Sistematis. Yogyakarta: Norma Media.

Suryani, L. (2014). Pengembangan Multimedia Pembelajaran Bahasa Arab Untuk Mahasiswa UIN Sunan Kalijaga Yogyakarta. Jurnal Inovasi Teknologi Pendidikan. 1 (1).

Zaenuddin, R. (2005). Metodologi dan Strategi Alternatif. Yogyakarta: Pustaka Rihlah Group.

Zaini, H., dkk. (2004). Strategi Pembelajaran Aktif. Yogyakarta, CTSD.

Zainudin, R. (2005). Pembelajaran Bahasa Arab. Jakarta: Pustaka Rihlah Group 